\title{
Hurler holes in Hunter syndrome
}

\author{
Rajaram Sharma (1) , ${ }^{1,2}$ Vikash Sharma, ${ }^{1}$ Tapendra Tiwari, ${ }^{1}$ Saurabh Goyal ${ }^{1}$
}

'Department of Radio-diagnosis, Pacific Institute of Medical Sciences Umarda Campus, Udaipur, Rajasthan, India ${ }^{2}$ Department of Radio-diagnosis, Seth GS Medical College and KEM Hospital, Mumbai, India

\section{Correspondence to} Dr Rajaram Sharma; hemantgalaria13@gmail.com

Accepted 29 October 2021

\section{Check for updates}

(C) BMJ Publishing Group Limited 2021. No commercial re-use. See rights and permissions. Published by BMJ.

To cite: Sharma R, Sharma V,
Tiwari T, et al. BMJ Case
Rep 2021;14:e246765.
doi:10.1136/bcr-2021-
246765

\section{DESCRIPTION}

A 16-year-old male presented to our hospital with complaints of mild mental retardation, umbilical and bilateral inguinal hernias, distended abdomen, profound bilateral hearing loss and recent onset seizures. On physical examination, he had a short stature, thick rough skin, depressed nasal bridge, macroglossia, macrocephaly, hypertrichosis and fixed joint abnormalities with contractures and scoliosis (figure 1, obtained with the patient's permission). No family history of a related syndrome was present on either the paternal side or the maternal side. The patient underwent ultrasonography of the abdomen, which revealed moderate hepatosplenomegaly, and umbilical and bilateral inguinal hernias. The patient underwent a urine spot test for mucopolysaccharidosis (MPS) type II screening, which came positive. Confirmatory analysis was performed by enzyme assay, which revealed diminished activity of iduronate 2-sulfatase enzyme in plasma at $1.2 \mathrm{~mol} / \mathrm{L} /$ hour (reference value: $>2 \mathrm{~mol} / \mathrm{L} /$ hour).

For further evaluation of his neurological symptoms, the patient underwent MRI findings that demonstrated bicoronal, lambdoid and sagittal synostosis with abnormal skull shape. Multiple welldefined rounded cystic lesions involving the corpus callosum were observed, which appeared hyperintense on T2-weighted image (WI) and hypointense on T1WI/fluid-attenuated inversion recovery (FLAIR) (figure 2A). Multiple tiny abnormal T2WI/ FLAIR hyperintense signal areas were noted in the periventricular and deep white matter in bilateral cerebral hemispheres (figure 2B) (appeared hypointense on T1WI, without any true restriction on diffusion-weighted imaging or any blooming on susceptibility-weighted imaging). Bilateral proptosis was present with prominent cerebrospinal fluid $(\mathrm{CSF})$ in the dural sheath over bilateral optic nerves (optic nerve sheath diameter- right $8.5 \mathrm{~mm}$ and left $9.5 \mathrm{~mm}$ ) (figure 2C). The MRI also depicted the prominence of extra-axial CSF spaces. In addition, a $2.1 \times 0.9 \times 1.5 \mathrm{~cm}$ sized extra-axial CSF signal intensity lesion was found in the right temporal region, representing prominent extra-axial CSF spaces/arachnoid cyst) (figure 2D). All the above findings suggested a diagnosis of MPS type II.

All investigations were in favour of MPS II. After diagnosis, the patient was started on enzyme replacement therapy. The patient is doing fine till the last follow-up.

Hunter syndrome (HS) is an X-linked recessive MPS type II syndrome caused by the deficiency of iduronate 2-sulfatase enzyme. This causes the accumulation of glycosaminoglycans (GAGs), dermatan and heparan sulfate in the body's extracellular and intracellular compartments, leading to multisystem organ abnormality. ${ }^{1} \mathrm{HS}$ is a heterogeneous

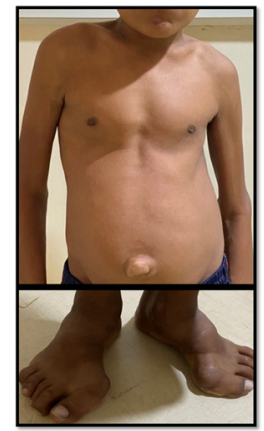

Figure 1 Clinical photograph of the patient with Hunter syndrome having classic features such as scoliosis, distended abdomen, umbilical hernia and flexion deformities in extremities.

disorder both in an age of onset of the symptoms and severity. It is labelled as mild and severe based on the survival length and the presence or absence of neurological symptoms .

Neuroradiological MRI in patients with HS is related to the deposition of GAGs and a strange flow of CSF into the brain parenchyma. The clinician can acknowledge a large spectrum of severity based on MRI findings, from negligible to severe. ${ }^{2}$ Typically, multiple prominent perivascular spaces (PVSs) are observed in the periventricular white matter and corpus callosum due to the deposition

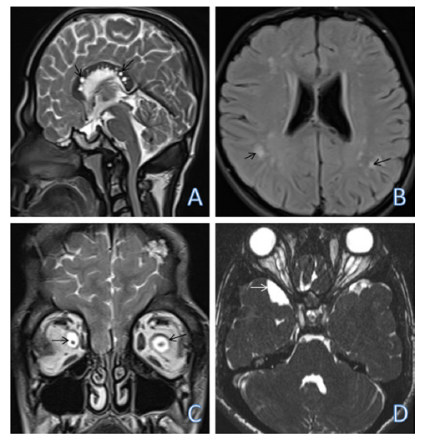

Figure 2 MRI findings in a 16-year-old male with Hunter syndrome: (A) Sagittal T2-weighted image of the brain demonstrates multiple well-defined rounded cystic lesions (Hurler holes) involving the corpus callosum (black arrow), and (B) axial fluid-attenuated inversion recovery image of the brain revealed symmetric periventricular and deep white matter involvement (black arrows). There is associated mild ventriculomegaly. (C) Coronal T2-weighted image of the brain shows prominent cerebrospinal fluid (CSF) in the dural sheath over bilateral optic nerves (black arrow), and (D) three-dimensional constructive interference in steady-state image shows extra-axial CSF signal intensity area in the right temporal region (white arrow). 


\section{Patient's perspective}

I belong to a middle-class socioeconomic background, and I came to know that my son is suffering from a rare disease. He appeared completely normal at birth. We suspected some abnormalities in him between 1 and 3 years of age. We took him to many hospitals, and we came to know about this rare disease, which is progressive and had a poor prognosis; this made me and my whole family very sad; seeing my child growing up as not usual is very painful; he was not able to do all work efficiently as his age group children do. Highly demanding care of my child had put much stress on my family and me. Then we came here, and the doctor counselled us very well; they answered all my queries regarding my child's treatment options and future prospects. They made us aware of the disability benefits and financial help available from various government agencies. My child was examined and investigated here entirely, and I hope that with the help of his study, other people will benefit and will also obtain knowledge about this rare disorder. This gives us motivation and power to live our lives better by helping my child improve his quality of life, like regular physical exercises to improve his joint movements. After coming to this hospital, we felt more confident about our child's treatment. of mucopolysaccharides, also known as Hurler holes. These PVSs look like fluid-filled spaces on MRI historically labelled as holes and may produce a classic sieve-like appearance of the neuroparenchyma. ${ }^{3}$ The Hurler holes are typical of both Hurler and Hunter syndrome. These Hurler holes are highly characteristic of MPS and are the key to diagnosis for the radiologist. In the appropriate clinical scenario, these classical MRI features may clinch the diagnosis of MPS. ${ }^{3}$ If these Hurler holes appear, it marks the advanced stage of the disease and hence worsens the prognosis. Thus, MRI plays an essential role in the further diagnostic work-up and follow-up of MPS.

Contributors RS and VS contributed to the planning, conduct, reporting, conception and design, acquisition of data, or analysis and interpretation of data. TT and SG contributed to the acquisition of data and interpretation of data.

Funding The authors have not declared a specific grant for this research from any funding agency in the public, commercial or not-for-profit sectors.

Competing interests None declared.

Patient consent for publication Consent obtained from parent(s)/guardian(s)

Provenance and peer review Not commissioned; externally peer reviewed.

Case reports provide a valuable learning resource for the scientific community and can indicate areas of interest for future research. They should not be used in isolation to guide treatment choices or public health policy.

\section{ORCID iD}

Rajaram Sharma http://orcid.org/0000-0003-1126-5875

\section{REFERENCES}

1 Gupta A, Uttarilli A, Dalal A, et al. Hunter syndrome with late age of presentation: clinical description of a case and review of the literature. BMJ Case Rep 2015;2015:bcr2015209305.

2 Reichert R, Campos LG, Vairo F, et al. Neuroimaging findings in patients with mucopolysaccharidosis: what you really need to know. Radiographics 2016:36:1448-62

3 Zafeiriou DI, Batzios SP. Brain and spinal MR imaging findings in mucopolysaccharidoses: a review. AJNR Am J Neuroradiol 2013:34:5-13.

Copyright 2021 BMJ Publishing Group. All rights reserved. For permission to reuse any of this content visit https://www.bmj.com/company/products-services/rights-and-licensing/permissions/ BMJ Case Report Fellows may re-use this article for personal use and teaching without any further permission.

Become a Fellow of BMJ Case Reports today and you can:

- Submit as many cases as you like

- Enjoy fast sympathetic peer review and rapid publication of accepted articles

- Access all the published articles

Re-use any of the published material for personal use and teaching without further permission

Customer Service

If you have any further queries about your subscription, please contact our customer services team on +44 (0) 2071111105 or via email at support@bmj.com.

Visit casereports.bmj.com for more articles like this and to become a Fellow 